\title{
The Pioneer Greek Immigrant in the United States and Canada (1880s- 1920s): Survival Strategies of a Traditional Family
}

\section{Evangelia Tastsoglou}

Ryerson University

\section{George Stubos}

York University

Tastsoglou, E., \& Stubos, G. (1992). The pioneer Greek immigrant in the United States and Canada (1880s-1920s): Survival strategies of a traditional family. Ethnic Groups, 9, 175-189.

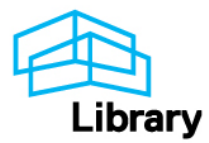




\title{
The Pioneer Greek Immigrant in the United States and Canada (1880s-1920s): Survival Strategies of a Traditional Family
}

\author{
EVANGELIA TASTSOGLOU and GEORGE STUBOS
}

Ryerson Polytechnical Institute, York University

\begin{abstract}
This paper is a study of the pioneer Greek immigrant and the pioneer Greek immigrant family in the United States and Canada from the 1880s to the 1920 s. Our thesis is that the pioneer Greek immigrant was the executor of a well-defined family plan to help preserve as much as possible the physiognomy, identity and economic autonomy of the family unit that was left behind in the mother country. The Greek-American and GreekCanadian family, limited in scope because of the gender composition of the early immigrants, organized itself in a "defensive" manner, i.e. it "closed" itself to the outside world and remained "frozen in time", as a result of the hardships of immigrant life, including the racism of the host countries.
\end{abstract}

KEY WORDS: Greek immigration, family, ethnic group survival, GreekAmerican and Greek-Canadian family

\section{INTRODUCTION}

It has been frequently argued in the literature that the family is anything but a static category. On the contrary, it is characterized by a web of multidimensional relationships between its members and between itself - as a unit - and the outside world. These relationships are affecting each other and are ever changing. The organization of the family unit depends on the institutional and socio-economic conditions prevalent in a given society and the everyday practices stemming from these conditions. The family unit has shown a remarkable adaptability to new conditions which almost always necessitate a modification of its functions both in terms of its modus operandi and modus vivendi.

Our study aims at illuminating certain socio-economic aspects of the first massive wave of Greek immigrants to the United States and Canada from the $1880 \mathrm{~s}$ to the $1920 \mathrm{~s}$. It is our contention in this paper that most of the atypical

Ethnic Groups, 1992

Vol. 9, pp. 175-189

Reprints available directly from the publisher

Photocopying permitted by license only
1992 C Gordon \& Breach Science Publishers S.A. Printed in the United Kingdom 
features exhibited by the early Greek immigrants can be attributed to a certain extent, to the structure, organization and function of the Greek family in its traditional habitat. In Greece, as in other Mediterranean countries, factors that range from economic scarcity to political instability, from religious beliefs to terrain particularities, and from deep rooted historical traditions to ignorant superstitions, molded the peasant family in two important ways: a) as an autonomous functioning unit in terms of its productive activity, and b) as an idiosyncratic social unit characterized by traditional, conservative and patriarchal intra-family relations well sustained by a well-knit web of kinship ties. On the other hand, the Greek immigrant family had to cope with an alien and often hostile socio-economic and cultural environment, which forced it to maintain as survival mechanisms many of these traditional traits, i.e. its patriarchal, authoritarian structure and strong kinship bonds.

\section{SOME ATYPICAL FEATURES OF THE EARLY GREEK IMMIGRANTS IN THE UNITED STATES AND CANADA}

The migration movement, that is central to our study, took place in the late 19th and early 20th century and coincides with the global movement to the United States. More precisely, between 1880-1920, 370,000 Greeks emigrated to the U.S.A. alone (Tsoucalas, 1982: 107). Other estimates raise the number of Greek immigrants to approximately 500,000 , if one takes into account those arriving from non-Greek territories and who, according to the American Census Bureau, were identified ethnically based on their place of birth which could have been Turkey, Russia and Egypt or some other European country with large Greek communities (1). During the same period immigration to Canada was very limited. According to the Canadian Census, in 1901 there were 291 Greeks residing in Canada. In 1911 the figure rose to 3,594, in 1921 to 5,740, and in 1931 to 9,444 with about half of them born in Canada and the rest having emigrated from Greece. (Chimbos 1980: 24-25).

The magnitude of the above numbers becomes more meaningful if it is assessed from a different perspective altogether. In the life span of a generation $1 / 7$ of the total population of Greece left for the New World (Polyzos N. 1945:50). Elaborating on the same data Tsoucalas (1982:110) comments that, "if we consider that immigration attracts exclusively male population between the ages of 18 to 40 , we may conclude that $25 \%$ of the total active population or $30 \%$ of the total active, agrarian population left Greece in a time span of 40 years" (see also Houliarakis 1973:143, 148).

The characteristics exhibited by the Greek immigrants, during this period 
were atypical if compared to those of other immigrant groups. K. Tsoucalas in his seminal work, already quoted above, Dependence and Reproduction, tirst published in French in 1975 and translated into Greek soon afterwards, elaborated extensively on those atypical characteristics. It is worth summarizing his major findings here, by referring to the original sources, where verification was possible, and by complementing his findings where necessary for the purpose of our own argument.

The first atypical feature relates to the predominantly male composition of the Greek immigrant population. From 1899 to 1910 for example, about 95\% of all Greek immigrants were males (Saloutos, 1964:45). In 1920 only 10.66\% of all those who migrated to the U.S. were women (Polyzos 1945:52, Psomiades and Scourby 1982:41). Comparative figures between immigrants from Greece and other nations indicate that, while the proportion between men and women for all immigrant groups in the U.S. was 121 to 100 , for Greeks the proportion was 443 to 100 (Vlachos, 1968:67). Jenks and Lauch (1912:170) point out that even the majority of Greek immigrants who were married, emigrated to the U.S. without their families. The situation in Canada was somewhat different. The ratio of women to men was approximately 1:2 (6,055 males and 3,389 females) (Vlassis, 1942:13).

A number of other studies also suggest that the majority of Greek immigrants never intended to stay permanently in the U.S., and "... to many of those their families back home always remained their point of reference" (Abbot G. 1909:380). Data available confirm this attitude. During the Balkan wars (1912-1914) 57,000 immigrants returned home to join the Greek army (Vlachos 1968:69). Between 1908 and 1930, 61\% of all Greek immigrants returned home (Polyzos 1945:69). By contrast, the Italian immigrant from the very beginning intended to bring the rest of his family to the New World, as soon as financial circumstances allowed him to do so (Sturino, 1978:294).

Another important and atypical characteristic of Greek immigrants is that they, more than any other ethnic group, preferred urban centres as their places of residence and work in spite of their peasant background (Fairchild 1911:117, Chimbos 1980:33). Data available from U.S.A. government sources indicate that in $192087.5 \%$ of the first generation Greek immigrants lived in urban centres (Vlachos 1968:75). At the same time only $0.1 \%$ worked as farmers (Polyzos 1945:53) (2). In terms of the overall occupational activities of the Greek immigrants, studies have shown that after the first difficult years, where the majority of them worked in low, menial jobs, such as dishwashers and cleaners, they soon showed an exceptionally high degree of occupational mobility. As Vlachos writes (1968:86) "during the first decade of this century there is not an American city without Greek-owned restaurants and other 
small businesses". Aggregate figures reveal that, with a U.S. national average of 100, the Greek immigrants were occupied with the following professions: in small business 290 ; in services 579 ; in manual work 74 ; in specialized manual work 27 (Tsoucalas 1982:152-153).

The last atypical characteristic of Greek immigrants was the fact that they were better educated in comparison with those from other countries with similar immigration movements. These figures, if compared with the national illiteracy rate of Greece, which was $60 \%$ for males in 1870 and $37 \%$ in 1920 , indicate that the immigrant population was better educated than the national average (Tsoucalas, 1982:154).

TABLE I

Percentage of illiterate immigrants

\begin{tabular}{lccccl}
\hline & 1895 & 1897 & 1898 & $1900-1914$ & \\
Greece & 28 & 13 & 20 & 25 & unrestricted \\
Italy (South) & 53 & 51 & 53 & 52 & unrestricted \\
Portugal & 62 & 57 & 61 & 65 & restricted \\
Spain & 14 & 7 & 13 & 11 & limited \\
\hline
\end{tabular}

Source: Cipolla C., Literacy and Development in the West, London, Penguin Books, 1969, pp. 96-97.

\section{A COMMENT ON THE GREEK IMMIGRANT FAMILY}

The gender composition of the first wave of Greek immigrants in the U.S. and Canada focuses the interest and the scope of a systematic analysis of the experience of the pioneer Greek immigrant family. At the risk of oversimplification and in a rather schematic way we would like to mention here that up to the 1910s the small number of Greek immigrant families had to struggle against tremendous odds. The difficulties of learning a new language and of adjusting to a foreign culture and an urban environment were compounded by the hostility, discrimination and racism they encountered by the white Americans and other ethnic groups which had preceded them to the New World.

Confronted with such problems the Greek immigrant in general and the Greek immigrant family in particular had to organize their life in a closed and "defensive" manner vis-a-vis the rest of society. Like the early Italian immigrants (Sturino, 1978), they would be received and helped to adjust in the New World by his kin, or he would foster strong bonds with people from the 
same village, with whom they would interact in their daily life and work. Kinsmen would be preferred over friends for social visits and mutual aid, while family and kinship celebrations would be quite common. Researchers found the early Greek immigrants to be "clannish" and "suspicious of other nationalities" (Walker, 1915. Xenides, 1922), with a high degree of intra-marriage (Bloom Wessel, 1944, Moskos, 1980:28). Intermarriages were very limited with most marriages arranged from afar by the family back in Greece, resulting in brides coming to North America without having met their husbands before. (Psomiades and Scourby, 1982:81, Vlachos, 1968:156, 157, Xenides, 1922:95, Vlassis, 1942:13, Chimbos, 1980:110-112, Papanikolas, 1989:30). Even their business transactions would be limited in the beginning to Greek clientele and then, as they became successful they would get expanded to the larger buying public (Moskos, 1980:20).

Consistent with this attitude of community isolation, an extensive network of Greek-language afternoon and Saturday schools was built after the turn of the century, while a great number of regional and cultural organizations flourished in all North American cities that had a Greek population of substantial size (Psomiades and Scourby, 1982:46. Polyzoi, 1986, Kopan 1989).

In order to survive in North America, the Greek immigrant family made a rigorous attempt to keep itself a cohesive group by keeping its gender role structure intact, and by preserving its strong patriarchal orientation and traditional values. The strict mores and the social conservatism of the early GreekAmerican family have remained notorious: As Saloutos writes (1964:315-316), the second generation girl was subjected to an even greater degree of subservience than her sister in Greece at the time. The proper roles for a young lady were limited to being a dutiful daughter, a competent housewife, and a devoted mother (Moskos, 1980:133). Marriages were mostly arranged, and divorce extremely uncommon (Xenides, 1922:91). There was a great emphasis placed on the chastity and purity of women, to the extent that the women who were travelling alone to America were burdened with the anxiety that they would be suspected forever of having questionable morals (Papanikolas, 1974:142). By contrast, male members of the family enjoyed a preferential treatment, clearly epitomized in the more relaxed moral code and social interaction patterns imposed upon them. On economic matters however, such a preferential treatment was not as pronounced in North America as it was in Greece, mainly because of the diminishing importance of dowry which traditionally turned sons to an asset and daughters to a liability (Kourvetaris, 1988:89).

These changes in family behaviour were not without regional variations. 
Papanikolas notes that Greek immigrant daughters in the West for instance, had more freedom than those in urban centers in the East and Midwest: "They drove cars, worked outside the home, could usually refuse marriage proposals, and groups of them took vacations together. As they grew older, they dropped more constraints" (1989:34-35). In the West in the early years, many married women ran boarding houses for Greek laborers. But it was in New England that the likelihood of women working was highest (Moskos, 1980:27).

A consequence of the small number of early immigrant women in the U.S. has been the strong "matrimonial culture" of the early Greek immigrant group. Because of the higher ratio of males in the early years, it was very rare to find spinsters among Greek women or in Greek-American immigrant families. Dowry was not an imperative as it had been the case in Greece and, unlike the custom in Greece, the bulk of the expense for the wedding was shouldered by the groom-elect, who often made a conspicuous display of his capacity to spend. The expenses of the parents were kept at an absolute minimum, a far cry from what they might have been in Greece (Saloutos, 1964:316).

In the North American context, family authoritarianism meant also a strained relationship between the older people and the new generation born there, an increased cultural lag between parents and children as well (Saloutos, 1964: 319-320, Kopan, 1989:56). Similar problems were faced by the Italian immigrant group as well (Pisani, 1957:131, 158-159).

The only exception to the insular and clannish life of the group was its systematic effort to guarantee secure roots for its offsprings by placing a heavy emphasis on their education, especially that of boys, as the only means by which they could survive and climb up the socio-economic ladder. The achievement motivation, diligence and willingness of the first immigrants' children to learn, as well as their parents' sacrifice and extensive support, have been widely documented in the literature (Dinnerstein and Reimers, 1988, Xenides, 1922, Rosen, 1959, Kopan 1989).

\section{TOWARDS A TENTATIVE ANALYSIS}

Reflecting on the atypical characteristics of the Greek immigrant in America between 1880 and 1930, we would like to put forward the following argument: the Greek immigrant in the U.S. during the period under consideration must be seen as the executor of a unique and well defined mission to help preserve as much as possible the physiognomy, identity and autonomy of the family 
unit that was left behind in the mother country. This argument can be substantiated and made more comprehensible if we illuminate some aspects of Greek family life and Greek society during the same period. In this section, we will also explain the character of the early Greek-American family and the relations among its members in terms of a) its cultural heritage of authoritarianism and patriarchalism, and its socio-economic modus operandi in Greece during the period under consideration, and b) its response to the hardships of early immigrant life in North America.

It is almost a convention in the relevant literature dealing with the Greek peasant family during the period under examination, to consider it as "economically autonomous" (Tsoucalas 1982; Vergopoulos 1975). This commonly accepted autonomy of the Greek peasant family as a productive unit is attributed to the radical land distribution policy introduced by the Greek state right after the liberation of Greece from Ottoman rule in 1828. As a result of this policy, the so-called, "national lands" were divided into small plots and distributed to all propertyless peasant families. Initially, the family unit operated at an absolute self-subsistence level where all basic needs were taken care by the family itself. It was only after the 1860 s, and due to the gradual re-orientation of Greek agriculture to respond to the needs of the international market for selected products (raisins, tobacco, olives), that the productive activity of the Greek family unit had to change, and it changed substantially. The routinization of agricultural production gave rise to an unprecedented high degree of under-utilization of family labour capacity. The magnitude of the above problem was amplified as a result of the general demographic pattern characterizing Greece during the second part of the 19th century. Due to the aggregate nature and unreliability of population statistics, this pattern can only be inconclusively assessed and only in a comparative perspective (3). From what is available, however, a number of hypotheses can be advanced in relation to the overall population increase; the degree of under-utilization of rural labour capacity; and the magnitude of the external migration movement.

We may justifiably assume, as Tsoucalas has done by referring to the relevant literature (1982: 97-104), that during the second half of the 19th century population growth patterns changed rapidly in Greece, as they did elsewhere in the Balkan peninsula and the rest of Europe. A number of factors contributed to this growth: a) the dramatic decline of infant mortality rate which fell from $30 \%$ in the beginning of the 18th century to an average of $20 \%$ between 1861-1884 and to $17 \%$ in 1900 (Cipolla 1967:71. Valaoras 1960:132); and $\mathrm{b}$ ) the increase by $10 \%$ of the life expectancy rate between the period of 1865 to 1926 (Tsaousis 1971:200). In spite of these indicators, however, a 
precise population growth pattern cannot be reliably estimated due to the constant territorial and population expansion of the Greek state during that period (3). What may be more illuminating in this respect is a comparison of population figures between Greece and neighbouring countries such as Bulgaria and Serbia, both of which enjoyed similar rates of population growth. The agrarian population of Greece from 1870 to 1907 increased by $17 \%$. In Bulgaria the agrarian population from 1881 to 1911 increased by $100 \%$; during the same period the agrarian population of Serbia increased by 80\% (Stavrianos S. 1958:442-445, 457-458. Zolotas X. 1926:42). The mere fact that the rural population in Greece increased only marginally, points to the conclusion that a massive exodus of its rural population was well under way during that period. This exodus of course had a profound effect on the under-utilization problem we mentioned before.

The effect of this massive immigration movement on the rural areas was obvious, at least in monetary terms. Even though it is almost impossible for us to estimate with precision the contribution of remittances to the family coffers back home, we can be sure that the regular, additional income coming from abroad constituted a very substantial part of the yearly family budget, and above all, as we will see later, it contributed to the preservation of family property and the formation of dowries for the female members of the family. Statistical data indicate that the annual remittances sent back home by Greeks living in the U.S. are much higher than those sent by any other ethnic group. The annual remittances sent back home by Greeks amounted to 50 dollars per capita, while for British and Irish immigrants the corresponding figure was 28.1 dollars; for Germans it was 4.05 dollars (Fairchild 1911:192; Saloutos 1969:43; Polyzos 1945:212). It has been estimated that, in a Greek village alone, from a total of 93,000 golden drachmas annual expenditure of the whole population, 37,000 or $40 \%$ had come from immigrant family members. Finally, Tsoucalas (1982:158) provides a more general picture with the following figures: the total direct taxation on agricultural production in 1910 reached 10 million golden drachmas; four years later, in 1914, the total remittances coming to Greece reached 65 million golden drachmas. From American sources we also learn that in 1905 alone the Greek immigrants sent to their families some 4 to 5 million dollars (Saloutos 1964:39). General as they may be, these numbers are indicative of the magnitude of economic assistance received by those families having relatives abroad.

The points raised thus far are suggestive of the fact that immigration was not the trait of the most poor and desperate families, neither must it be seen as a massive and indiscriminate departure of unemployed young men. On the contrary, immigration was the result of careful family planning and of a selec- 
tion process that aimed at minimizing the risks of failure, by sending abroad the son with the best credentials possible in order to have a rewarding experience for himself, as well as for his family. In other words, immigration was the result of a well thought out and executed family plan.

Appraised from a different perspective, the departure of a male member for a limited stay in North America was intended to diversify the economic resources of the family and, in doing so, safeguard and protect the modus vivendi of the family members who stayed behind. More precisely, the family unit was hoping to preserve through immigration its property base and be in a position therefore to satisfy its economic and social obligations to its members especially in the form of dowry and inheritance (4). In fulfilling these obligations and responsibilities the family unit was in a position to preserve its identity and protect the honour of its members.

In order to better understand the socio-economic modus operandi of both a) the early Greek immigrant group in North America and b) the early Greek immigrant family there - limited in scope as it was - we need to describe next how the social world of the extended peasant family back in Greece was constructed, i.e. to describe the positions and roles of its members, welldefined, by tradition and economic functions, which formed the basis of their interpersonal relations.

The family unit in Greece, during the period under consideration, is characterized by a patriarchal and authoritarian structure which, by its very nature, fosters a vertical and downward chain of command from the father to all other family members (mother, sons, daughters and in that order). The relationship between husband and wife was anything but egalitarian. The regional variations, and their interpretations, range from agonistic and hostile relationship with severe restrictions imposed on women's free movement and expression (Campbell, 1963), to complementary but clearly demarcated roles and spheres of activity (Danforth, 1980. Sanders, 1962, Clark, 1980, Salamone, 1987). Overall, women were in the shadow of men in the family and in the marketplace (Campbell, 1964), though in regions (especially islands) where men were making their living by travelling for extended periods of time, women exercised extensive administrative and managerial duties with respect to their family and property (Petronoti, 1981).

Marriage itself is seen in terms of its functions rather than in terms of individual fulfilment and happiness. Such functions include the transfer of property in the form of dowry; the establishment of community alliances and the prospect of broader kinship ties; and, last but not least, the bearing of children. Marriage as a partnership could survive even if communication among spouses was minimal or non-existent (Potamianou, 1982), so long as 
no serious questions of infidelity or any "incident" inflicting damage to the honour and moral reputation to either of the spouses, manifested itself.

In the context of political and economic alliances, the dowry system must be examined as well. Although there are regional, class, and time variations during the period under consideration, with respect to the degree of importance and nature of the dowry (Friedl, 1967. Campbell, 1963. Du Boulay, 1980. Symeonidou-Alatopoulou, 1979. Lambiri-Dimaki, 1972. Teperoglou, 1972), there is a significant exchange of resources, transfer and consolidation of property taking place, as two parties unite in marriage. In such a transaction, choice is rather limited (Sanders, 1962. Du Boulay, 1980), and both parties are looked upon as valuable commodities, especially the woman, who also has to contribute chastity (Allbaugh, 1953), honour, and beauty to the marriage contract. If she violates the community's sexual code of behaviour, she and her child are ostracised and run the danger of getting killed by their kin (Campbell, 1968).

The emotional ties between mother and children are very strong, especially in rural Greece, in the period under consideration. For the mother, the notyet married daughter is a friend, a confidante, and a working partner in the house and the fields (Friedl, 1967). The presence of a grandmother in the household had only a re-enforcing effect on these emotional ties. The only female relationship loaded with tension and even conflict is that between mother-in-law and daughter-in-law (Bialor, 1963), a relationship which, to a great extent, reflects the degree of satisfaction or dissatisfaction of the two households that were socially and economically connected through the prearranged marriage.

The father has also a clearly pre-defined role to play. He is responsible for safeguarding family honour and primarily for finding brides and grooms for his children. He is also responsible for subdividing family property and distributing it to his children. Finally, he is responsible for maintaining social and economic ties with his brothers, male relatives and other members of the community for the purpose of achieving the above mentioned family goals and objectives.

The role of children is equally well demarcated; sons and daughters, are by far the most valuable assets of the family not only emotionally but also socially and economically. The son is expected to contribute to the maintenance and further increase of family property and wealth through his own labour and even through a successful marriage accompanied by a large dowry that could enrich the family's assets. At the same time the son is co-responsible with his father for providing a dowry to his sister(s) who, from their part, were expected to reduce the dowry burden on the family by bringing chastity and honour to 
the pre-arranged marriage. What must be emphasized here is the separation between son/daughter roles. Sons are principally accountable, together with their father, for settling the family's economic obligations, while daughters are expected to adhere to a strict moral/sexual code, and, in doing so, preserve and protect the social reputation of the family unit and, at the same time, increase their chances for a good marriage with the smallest dowry possible.

But the organizational structure of the Greek family in North America was determined not only on the basis of its traditional heritage from Greece, but also as a result of the hostility and racism it encountered in the New World. It was not unusual for Greeks in the American West (Utah, Nebraska) in the first two decades of the century to be described in the newspapers as "scum of Europe", and "unfit for citizenship" and they were often the target of organized attacks and terrorism by the Ku Klux Klan (Moskos, 1980:16, Saloutos, 1964:70, Papanikolas, 1989:28). In 1909 in the city of South Omaha, Nebraska, the mob rampaged through the Greek quarter burning most of it to the ground, destroying some thirty-six Greek businesses, and driving all the Greeks from the city. In 1918 extensive anti-Greek riots and clashes with the police took place in Toronto, resulting in injuries and damage of GreekCanadian property (Chimbos, 1980:38-40).

Given these conditions, the pioneer Greek immigrant family had to organize its life in a defensive manner vis a vis its new alien and hostile environment with the hope of ensuring its preservation and protection (Tavuchis, 1972). Kinship relations and bonding were kept and even reinforced as in the old country to ensure the immigrants' survival. The overall response of the Greek family to the foreign language, laws, customs, and ways of the people, was to keep well interconnected, and apart from the rest of the society.

This apparent relative isolation of the Greek-American immigrant group both from the mainstream American culture and also the Greek culture of their time, resulted in a situation where the first Greek immigrants (especially first generation) remained culturally, socially, and emotionally "frozen in time" (5), with a point of reference the moment they left their village community for the New World. This attitude epitomized itself clearly in the rigorous attempt of the Greek immigrant family to keep gender roles unchanged, together with its strong patriarchal orientation, traditional values and intra-group solidarity. Similar patterns of family and social organization were followed by another immigrant group, the Italians, as a result both of the hostility and alienation that the early immigrants experienced in North America, and of their own historic - cultural legacy in Italy (Pisani, 1957:5254, 60-62, 200-209. Also, Moquin and Van Doren, 1974:255-258, Perin and Sturino, 1989:126-127). 


\section{CONCLUSION}

The decision to emigrate was a family decision imposed by the severity of the financial difficulties that the Greek peasant family found itself under during the second half of the 19th century. The routinization of agricultural production during this period, due to the single commodity orientation imposed by the needs of the international market, in conjunction with the high rate of population characterizing Greece at the time, contributed to an unprecedented high degree of under-utilization of family labour capacity. Faced with such an economic crisis and determined to survive and preserve its identity and autonomy the Greek peasant family had no other alternative but to proceed to a radical re-organization of itself and a re-definition of the roles and functions of its members. The nature of this "re-organization" and "re-definition" is uniquely exhibited in the collective decision of the Greek peasant family to send to North America one of its male members - most often the one with the best chances to succeed. In doing so, the economic assets of the family unit were more fully utilized, while the integrity, cohesion, prestige and family honour were preserved, and, more importantly, all these family objectives were achieved within the boundaries of traditional and conservative values so characteristic of rural life in Greece during the period under examination in this study.

Concerning the early Greek family in North America, limited as it was in scope, it remained a traditional, "institutional" form of family, i.e. existing for the sake of its functions, as it had been in its origins in Greece, and despite the cultural pluralism and different material conditions of life in North America. As a result mainly of the hostility and hardships that the pioneer immigrant groups faced, they had to organize themselves in the defensive manner that was described above, looking at the kinship group for alliance and support and remaining "frozen in time". The family was maintained primarily for its functions, i.e. reproduction, the socialization of children, and the fulfillment of economic and social tasks, as opposed to its later evolution, following the general direction of the modern family in North America, toward a "relational" form, i.e. the type of family existing as a result of the quality of interpersonal relationships among its members (6). We should not overlook the fact, however, that the family in Greece as well as in North America during that period was also "institutional" in its form, maintained for the sake of its functions, patriarchal and authoritarian. 


\section{REFERENCES CITED}

Abbot G. (1909). "A Study of Greeks in Chicago". American Journal of Sociology, XV.

Allbaugh, Leland G. (1953). Crete. Princeton University Press.

Bialor, Perry. (1963). "Tensions Leading to Conflict and the Resolution and Avoidance of Conflict in a Greek Farming Community". Contributions to Mediterranean Sociology. Athens.

Bloom Wessel, Bessie. (1944). "The Ethnic Survey of New London, Connecticut, 1938-1944. A Resurvey After Some Twenty Years", The American Journal of Sociology, Sept. 1944, vol. 50, pp. 85-98.

Campbell, J. K. (1963). "The Kindred in a Greek Mountain Community". Mediterranean Countrymen. Ed. by Julian Pitt-Rivers. Mouton \& Co/Maisons des Sciences de l'Homme.

Campbell, J. K. and Philip Sherrard. (1968). Modern Greece. London: Ernest Benn Limited.

Campbell, J. K. (1964). Honour, Family, and Patronage. Oxford University Press.

Chimbos, Peter, D. (1980) The Canadian Odyssey. The Greek Experience in Canada. Toronto, McLelland and Stewart.

Cipolla, C. (1969). Literacy and Development in the West. London, Penguin.

Cipolla, C. (1967). Economic History of World Population. London, Penguin.

Clark, Mari H. (1980). "Variations on Themes of Being Female and Male: Gender in Fieldwork in Rural Greece", paper submitted in the Symposium of the Modern Greek Studies Association in Philadelphia.

Danforth, Loring. (1980). "Power through Submission in the Anastenaria". Paper submitted in the Symposium of the Modern Greek Studies Association in Philadelphia.

Demos, Vasilikie. (1989). "Maintenance and Loss of Traditional Gender Boundaries in Two Greek Orthodox Communities". Journal of the Hellenic Diaspora, 1989:77-93.

Dieterich, K. (1918). Hellenism in Asia Minor. New York.

Dinnerstein, Leonard and David M. Reimers, (1988). Ethnic Americans, 3rd edition, Harper and Row.

Du Boulay, Juliet. (1980). "The Meaning of Dowry. The Symbolic Position of Women in Rural Greece". MGSA Symposium, Philadelphia.

Fairchild H. P. (1911). Greek Immigration to U.S. new Haven and London.

Frangis, Maria, B. (1978). "An Ancient Heritage in a New World" in The Ethnic American Woman: Problems, Protests, Lifestyle, ed. by Edith Blicksilver. Dubuque, Iowa, Kendall/Hunt.

Friedl, Ernestine. "The Role of Kinship in the Transmission of National Culture to Rural Villages in Mainland Greece". East European Peasantries: Greece, vol. 1.

Friedl, Ernestine. (1967). Vassilika. N.Y.: Holt, Rinehart \& Winston.

Houliarakis M. (1972). See article in Statistical Studies 1827-1971. EKKE, Greek ed., Athens.

Ioannou, Tina. (1983). Communaute Greque Du Quebec. Institute Quebecois de Recherche sur la Culture.

Jenks J. and Lauch W. (1912). The Immigration Problem. New York.

Kataki, Charis, D. (1984). The Three Identities of the Greek Family. Athens, Kedros. (In Greek).

Kondogiannis K. (1919). The Greek Identity of the Provinces of Prousa and Smyma. Greek ed. Athens.

Kopan, Andrew, (1989). "The Greeks of Chicago: The Survival of an Ethnic Group Through Education". Fournal of the Hellenic Diaspora. 1989: 47-59.

Kouroucli, M. (1984). "The Family in 19th-Century Corfu". Aspects of the 19th Century Greek Society. Athens, Estia (in Greek).

Kourvetaris, George. (1988). "The Greek American Family", Ethnic Families in America. Ed. by C. Mindel, R. Habenstein, and R. Wright. New York, Elsevier.

Lambiri-Dimaki, Jane. (1972). "Dowry in Modern Greece: An Institution at the Crossroads Between Persistence and Decline". Toward a Sociology of Women, ed. by Constantina SafiliosRothschild. Lexington, Mass: Xerox College Publishing.

Mitchell P. B. (1971). The Fontana Economic History of Europe. London. 
Moquin, Wayne with Charles Van Doren. (1974). A Documentary History of the Italian Americans. NY: Praeger.

Moskos, Charles, C. Jr. (1980). Greek Americans. Struggle and Success. Englewood Cliffs, PrenticeHall.

Mousourou, Loukia, M. (1987). "Family and Child in Athens". Sociology in Greece Today. Athens, Papazisis (in Greek).

Papanikolas, Helen. (1987). Emily - George. Salt Lake City, University of Utah Press.

Papanikolas, Helen. (1989). "Greek Immigrant Women in the Intermountain West", Journal of the Hellenic Diaspora. 1989:17-35.

Papanikolas, Helen Zeese. (1974). Toil and Rage in a New Land: The Greek Immigrants in Utah. Salt Lake City: Utah Historical Society.

Perin, R. and F. Sturino. (1989). Arrangiarsi. The Ilalian Immigration Experience in Canada. Montreal, Guernica.

Petronoti, Marina. (1985). "Design for the Study of the Economic and Social Developments in Kranidi (1821-1981)", Review of Social Research, 57 (in Greek).

Petroroti, Marina, (1981). "The Economic Autonomy of Rural Women", Review of Social Research. 41, Jan.-April.

Pisani, Lawrence F. (1957). The Italian in America. NY: An Exposition - University Book.

Polyzoi, Eleoussa. (1986). "Greek Immigrant Women from Asia Minor in Prewar Toronto: The Formative years", Looking into my Sister's Eyes: An Exploration in Women's History. Toronto, The Multicultural History Society of Ontario.

Polyzos, N. (1945). L' Emigration Greque. Paris.

Potamianou, A. (1982). "The Dynamic of the Greek Family", Modern Issues, v. 14, March (in Greek).

Psomiades Harry J. and Alice Scourby (eds), (1982). The Greek American Community in Transition. NY: Pella.

Rosen, Bernard, C. (1959). "Race, Ethnicity, and the Achievement Syndrome", American Sociological Review, 24:1, pp. 47-60.

Salamone, Stephen D. (1987). "Tradition and Gender: The Nikokyrio. The Economics of Sex Role Complementarity in Rural Greece", Ethos, 15(2).

Saloutos, Theodore. (1956). They Remember America: The Story of the Repatriated Greek-Americans. Berkeley: Univ. of California Press.

Saloutos, Theodore. (1964). The Greeks in the United States. Cambridge, Harvard Univ. Press.

Sanders, Irwin. "Greek Society in Transition". East European Peasantries: Greece, vol. III."

Sanders, Irwin. "The Nomadic Peoples of Northern Greece". East European Peasantries: Greece, vol. 1.

Sanders, Irwin. "Village Social Organization in Greece". East European Peasantries: Greece, vol. 1.

Sanders, Irwin. (1962). Rainbow in the Rock. Cambridge University Press.

Stavrianos, S. (1958) The Balkans Since 1453. N.Y. Rinehart.

Sturino, Franc. (1978). "Family and Kin Cohesion among South Italian Immigrants in Toronto", in The Italian Immigrant Woman in North America, ed. By Betty Boyd Caroli, Robert F. Harney, Lydio F. Tomasi. Toronto, The Multicultural History Society of Ontario.

Symeonidou-Alatopoulou, Charis. (1980). "Female Labour Force Participation in Greece". The Greek Review of Social Research, vol. 38.

Symeonidou-Alatopoulou, Charis. (1979). "I Exelixi tou Thesmou tis Prikas stin Ellada, 19561974" (The Development of the Institution of Dowry in Greece, 1956-1974). The Greek Review of Social Research. Vol. of May-December.

Tavuchis, Nicholas. (1972) Family and Mobility Among Greek-Americans. Athens: National Centre of Social Research.

Teperoglou, A. (1972). "I Prika os Synchronon Kinonikoikonomikon Phenomenon" (The Dowry as a Modern Socioeconomic Phenomenon), Anthropines Scheseis (Human Relations). vol. A 1. 
Tsorvas, Ourania H. (1989). "Highlights of a Study of the Mobility and Social Characteristics of the Greek Population of Bridgeport, Connecticut, 1900-1970". Journal of the Hellenic Diaspora, pp. 95-103.

Tsoucalas, Constantinos. (1982). (Orig. 1975, in French). Dependence and Reproduction. Athens, Themelio (in Greek), 3rd edition.

Vergopoulos, Kostas. (1975). The Agrarian Issue in Greece, (in Greck). Athens, Exantas.

Vlachos, Evangelos, C. (1968). The Assimilation of Greeks in the United States. Athens, National Centre of Social Researches.

Vlassie, Katherine. (1987). Children of Byzantium. Winnipeg, Cormorant Books.

Vlassis, George, D. (1942). The Greeks in Canada. Ottawa.

Walker, Natalie. (1915). "Chicago Housing Conditions. Greeks and Italians in the Neighborhood of Hull House", Fournal of Sociology, Vol. 21:3, pp. 285-316.

Xenides, J. P. (1922). The Greeks in America. NY: George H. Doran.

\section{NOTES}

1. It should be noted that in the city of Smyrna alone, by $1887,20,000$ Greeks out of a population of 120,000 were born in Greece (Kontogiannis K. 1919:209). In 1920 the Greeks living in Russia were over 600,000 . The Greek communities in Egypt had a population of over 200,000 by 1920 (Tsoucalas 1982:108).

2. Another immigrant group that preferred and heavily concentrated in urban, industrial areas, despite its peasant origin, were the Italians (Pisani, L. F., 1957:66).

3. The territorial expansion and population growth of Greece continued all during the 19th and 20th centuries.

$\begin{array}{lcc} & \mathrm{km} 2 & \text { Population } \\ 1828 & 47,512 & 1 \mathrm{mil} . \\ 1870 & 50,211 & 1.4 \mathrm{mil} . \\ 1889 & 63,606 & 2.2 \mathrm{mil} . \\ 1920 & 127,606 & 5.6 \mathrm{mil} . \\ 1930 & 127,606 & 6.2 \mathrm{mil} .\end{array}$

Source: Greek National Bureau of Statistics, 1933.

4. It is clearly illustrated by the information provided in the table below that the massive agrarian exodus during the 19 th and 20 th century, was not accompanied by an abandonment of family land holdings or by a noticeable concentration of land. On the contrary, the diversification of economic activities within the family unit, resulted in a remarkable preservation of family property.

$$
\text { No. of plots }
$$

1928

1951

1961

$$
953,367
$$

Size of plots

3.77 acres

3.59

3.22
Persons/plot

3.46

3.57

3.11

5. The term that has been used in the literature to describe such an attitude (and mode of adaptation), especially in the second generation, is "cultural atavism", i.e. an inward, retrogressive orientation and identification with an ethic "greek" life-style (Kourvetaris 1988:92).

6. The concepts have been adapted from David H. J. Morgan's work, "Institution and Relationship Within Marriage" (paper presented at the XIIth World Congress of Sociology, Spain, July 9-13, 1990), to apply to the conceptual understanding of the changes that took place in the family, with the increasing industrialization in the European and North American societies in the twentieth century. 